Olena Proskurniak,

Doctor of Psychology,

Head of the Department of Correctional Education and Special Psychology, Municipal institution "Kharkiv Humanitarian-Pedagogical Academy" of Kharkiv Regional Council,

\title{
DIAGNOSTIC METHODOLOGY OF COMMUNICATIVE ACTIVITY DEVELOPMENT LEVELS IN ADOLESCENTS WITH MENTAL RETARDATION
}

Communication is a leading activity in adolescence. Due to the peculiarities of mentally retarded adolescents' cognitive sphere, they have certain complications in communication that affect socialization and adaptation processes, relationships with others. To create a technique of development and correction of communicative activity in adolescents with mental retardation it is necessary to determine communicative activity formation levels. However, studies analysed have proved that there is no complex diagnostic methodology of communicative activity. It determines the relevance of this research. The aim of the article is to illustrate peculiarities of creation of psychodiagnostic methodology for determining levels of communicative activity development in adolescents with mental retardation. To achieve the goal, the research methods to measure the range of techniques diagnosing mentally retarded adolescents' communicative activity, methods of mathematical statistics for validity and reliability verification, generalization of scientific and practical achievements have been used. 300 adolescents with mental retardation have been examined with the help of the final version of the developed methodology. Psychological diagnostic methodology of communicative activity development in adolescents with mental retardation in its final version consists of five scales. Due to the content of statements the first scale is defined as "communicative activity". The second one is "communicative competence". The third scale is "communicative culture". The fourth one is "communicative behaviour". The fifth scale is "self-control of personality in communicative activity". Based on the used diagnostic tools, levels of communicative activity formation (high, medium, low) have been identified and characterized.

Keywords: adolescents, mental retardation, communicative activity, diagnostics, methodology, development.

\section{Introduction}

Studying communicative activity formation in individuals with mental retardation, a special prominence is given to adolescence, which is characterized by an increased demand for communicative interaction with others, on the one hand, and a certain deceleration in the dynamics of cognitive processes development that, in general, negatively affects communicative knowledge, abilities and skills acquirement that would contribute to adequate communicative behaviour, on the other hand.

Despite a great number of scientific works devoted to the peculiarities of mentally retarded pupils' communicative activity, they are the least studied and the most controversial phenomena. It is caused by the complexity and systematic disorders of intellectual sphere (V. Bondar, L. Vygotsky, Yu. Bystrova, T.Viskovatova, L. Rudenko, Ye. Synyova, T. Sak, V. Tarasun, G. Dulnev, M. Pevzner, V. Petrova). However, studies analysed have proved that there is no complex diagnostic methodology of communicative activity formation in mentally retarded adolescent pupils. So, the necessity to create a new psychodiagnostic methodology for determining levels of communicative activity development is evident.

The aim of the article is to illustrate peculiarities of creation of psychodiagnostic methodology for determining levels of communicative activity development in adolescents with mental retardation. The following tasks have been set:

1) to ground the appropriateness of psychodiagnostic methodology development according to the structure of communicative activity;

2) to reveal peculiarities of diagnostic methodology development;

3) to prove the feasibility of its implementation for determining levels of communicative activity formation in mentally retarded adolescents.

Research methods

To achieve the goal, the research methods to measure the range of techniques diagnosing mentally retarded adolescents' communicative activity, methods of mathematical statistics for validity and reliability verification (cluster and factor analysis, Pearson and Spearman's coefficients), generalization of methodic, scientific and practical achievements have been used.

\section{Discussion}

In the process of psychodiagnostic methodology creation we based on the structure of communicative activity which consists of motivational, cognitivesemantic and operational-behavioural components [7]. Based on the analysis of theoretical sources we have found personal and social needs that define communicative activity of personality in the motivational component; in the cognitive-semantic - communicative competence 
and culture, which are determined by communicative qualities, knowledge, abilities and skills; in the operational-behavioural - communicative behaviour that meets the norms of behaviour in society and is achieved through self-regulation.

According to indicators of communicative activity of mentally retarded pupils and their components, diagnostic methodology of communicative activity development levels in adolescents has been developed.

To ensure the validity of diagnostic methodology of communicative activity development in adolescents the original version of it included 74 items, which were presented in the form of statements and characterized communicative activities according to the above mentioned indicators.

The questionnaire sentences were given in a simplified form and could be understood by both older and younger teenagers. It should be noted that the questionnaire was developed for mentally retarded adolescents. Statements included both direct and converse characteristics of communicative activity components, placed in a mixed order to avoid wrong students' behaviour during the interview. Direct statements characterize communicative manifestations positively, converse statements - their non-development.
The questionnaire was developed according to the scale with the following poles: 3 - yes, 2 - sometimes, 1 - no, according to which students were awarded points. In direct statements the amount of points was left, and in converse statements - calculated according to the reverse ratio of $3: 1$. The statements indicating communicative activity development got high scores, non-development low scores. The total score indicated communicative activity development level of an adolescent.

The initial pilot study involved 360 students with mental retardation (ranging in age from 12 to 15).

For processing the results of the initial study the programs SPSS 20.0 and EXCEL 2003 for Windows were used. In the pilot phase indicators of discriminativeness and internal consistency were determined for all 74 proposed items in order to remove the items that have low psychodiagnostic significance.

Consequently, development and standardization of methodology were carried out in accordance with test design requirements [1].

After the initial pilot study, according to psychodiagnostic methodology design rules, the second stage was conducted (multidimensional scaling was done with the help of primary test form) (see Table1).

Table 1. Psychometric characteristics of items of diagnostic methodology of communicative activity development
in adolescents with mental retardation, resulting from multidimensional scaling (in conventional units)

\begin{tabular}{|l|}
\hline Formatrix \\
\hline Stress $=0,11597 \mathrm{RSQ}=0,19645$ \\
\hline
\end{tabular}

\begin{tabular}{|c|c|c|c|c|c|}
\hline Stimulus Number & 1 & 2 & 3 & 4 & 5 \\
\hline \multicolumn{6}{|l|}{ "Communicative activity" Scale } \\
\hline 1. I like communicating with peers & 0,6843 & & & & \\
\hline 2. I can easily get to know people & 0,7562 & & & & \\
\hline 3. Travelling is interesting & 0,71911 & & & & \\
\hline 4. I don't like to talk about myself and my business* & 1,6246 & & & & \\
\hline $\begin{array}{l}\text { 5. I don't like to explain to people how to get to the } \\
\text { nearest pharmacy* }\end{array}$ & 0,6790 & & & & \\
\hline $\begin{array}{l}\text { 6. I can always find a topic for conversation with peo- } \\
\text { ple }\end{array}$ & 0,8670 & & & & \\
\hline $\begin{array}{l}\text { 7. I will happily answer on the street how to get to our } \\
\text { school }\end{array}$ & 0,8800 & & & & \\
\hline \multicolumn{6}{|l|}{ "Communicative competence" Scale } \\
\hline $\begin{array}{l}\text { 8. People around me always understand what I'm } \\
\text { speaking about }\end{array}$ & & 1,9951 & & & \\
\hline 9. I find it difficult to express my thoughts* & & 0,950 & & & \\
\hline $\begin{array}{l}\text { 10. I often interrupt interlocutors to make them listen to } \\
\text { me }^{*}\end{array}$ & & 1,8790 & & & \\
\hline 11. I always tell about my school day at home & & 0,7546 & & & \\
\hline 12. I know how to behave in unknown places & & 0,6390 & & & \\
\hline \multicolumn{6}{|l|}{ "Communicative culture" scale } \\
\hline 13. I greet my acquaintances & & & 1,1144 & & \\
\hline 14. I don't speak with nasty people at all* & & & 0,7955 & & \\
\hline 15. I don't communicate with some of the classmates* & & & 1,1004 & & \\
\hline
\end{tabular}




\begin{tabular}{|l|l|l|l|l|l|}
\hline \multicolumn{5}{|l|}{ Table 1. } \\
\hline Stimulus number & 1 & 2 & 3 & 4 & 5 \\
\hline 16. I wish my relatives and friends happy holidays & & & 0,548 & & \\
\hline 17. I try to be polite talking to people & & & 1,8778 & & \\
\hline 18. If I hurt someone, I apologize & & & 1,3476 & & \\
\hline 19. I can mock aloud at my peers* & & & 1,8422 & & \\
\hline "Communicative behaviour" Scale & & & 1,1468 & \\
\hline 20. When I'm in a bad mood, everyone knows about it* & & & & 0,9428 & \\
\hline 21. I support conversations with pleasure & & & & 1,5766 & \\
\hline $\begin{array}{l}\text { 22. If I've lost my friend's exercise book, I will apolo- } \\
\text { gize then }\end{array}$ & & & & 1,6884 & \\
\hline 23. I talk to people in a friendly way & & & & 0,6484 & \\
\hline 24. I don't like rude people & & & & 0,9882 & \\
\hline $\begin{array}{l}\text { 25. Sometimes I forget to comply with my friends" } \\
\text { requests }\end{array}$ & & & & & 0,8564 \\
\hline "Self-control of personality in the communicative activity" scale & & & & & 1,2486 \\
\hline $\begin{array}{l}\text { 26. I can hide from surrounding people that there's } \\
\text { something in them I don't like }\end{array}$ & & & & & 0,6486 \\
\hline 27. I am often intemperate in my speech* & & & & & 1,2333 \\
\hline 28. I overreact to insults* & & & & & 1,4896 \\
\hline $\begin{array}{l}\text { 29. I think that those who surround me can determine } \\
\text { my mood by my facial expression* }\end{array}$ & & & & & 2,0423 \\
\hline $\begin{array}{l}\text { 30. When I am happy, I tell all my acquaintances about } \\
\text { it }\end{array}$ & & & & & \\
\hline 31. I am reserved even in disputes & & & & & \\
\hline 32. I find it difficult to control my speech \\
*- converse statements
\end{tabular}

Multidimensional scaling in the primary version has made it possible to divide questions into three scales which reflect motivational, cognitive-semantic and operational-behavioural components of communicative activity. The stress level according to the primary analysis was 0,19645 . Consequently, the three-component structure of communicative activity was experimentally proved.

The re-use of multidimensional scaling allowed us to identify five scales that represent indicators of communicative activity in accordance with each component. The data obtained are presented in Table 1 and show that the first scale includes questions which define the meaning of communicative activity in adolescents, the second one includes questions that reflect communicative culture, the third one - communicative competence, the fourth one communicative behaviour, the fifth one - self-control of personality in communicative activity.

At the next stage of development cluster analysis was used. With the help of a dendrogram (SPSS 20.0) clusters were determined. It allowed to exclude questionnaire statements, which were identical in content [5]. As a result, the methodology had 32 statements that were given to respondents again.

According to diagnostic methodology design rules the next stage was to determine Cronbach's alpha in order to identify internal consistency of statements. The data obtained prove the acceptable internal consistency of statements and are given in Table. 2.

Table 2.

Evaluation of internal consistency (Cronbach's alpha)

\begin{tabular}{|l|l|l|}
\hline \multicolumn{3}{|c|}{ Reliability Statistics } \\
\hline $\begin{array}{l}\text { Cronbach's al- } \\
\text { pha }\end{array}$ & $\begin{array}{l}\text { Cronbach's alpha based on } \\
\text { standardised items }\end{array}$ & The number of items \\
\hline 0,527 & 0,560 & 32 \\
\hline
\end{tabular}

Methodology reliability was tested in the following ways: Cronbach's alpha - evaluation of internal consistency, evaluation of re-test reliability (re-test was conducted in two months), evaluation of reliability by splitting method. Statistical data of these methods proved the acceptable reliability level of the developed methodology. The results of reliability testing are presented in Table 3.
In the final version the methodology was given to 360 adolescents with mental retardation.

Diagnostic methodology of communicative activity development levels in adolescents with mild and moderate degrees of mental retardation included five scales in its final version. 
Table 3.

Statistics calculations of methodology items

\begin{tabular}{|l|l|l|l|l|l|l|l|}
\hline \multicolumn{9}{|c|}{ Summary statistics of the item } \\
\hline & Average & Minimum & Maximum & Range & $\begin{array}{l}\text { Maxi- } \\
\text { mum/Minimum }\end{array}$ & Dispersion & $\begin{array}{l}\text { The number } \\
\text { of items }\end{array}$ \\
\hline Average items & 1,786 & 0,9688 & 2,627 & 1,600 & 2,141 & 0,246 & 32 \\
\hline Dispersion of items & 0,545 & 0,196 & 0,606 & 0,541 & 4,008 & 0,016 & 32 \\
\hline $\begin{array}{l}\text { Inter-item covaria- } \\
\text { tions }\end{array}$ & 0,018 & $-0,164$ & 0,272 & 0,364 & $-0,915$ & 0,008 & 32 \\
\hline $\begin{array}{l}\text { Inter-item correla- } \\
\text { tions }\end{array}$ & 0,058 & $-0,432$ & 0,966 & 1,388 &,- 979 & 0,042 & 32 \\
\hline
\end{tabular}

Due to the content of statements the first scale was defined as "communicative activity" characterizing needs in communicative interaction of personal and social orientation [2]. The second scale - "socio-communicative competence" - defined appropriate knowledge, communicative qualities, abilities, skills in planning communication activities through communicative skills formation [3]. The third scale is "communicative culture", statements of which helped to reveal knowledge about rules of communicative interaction in different situations, tolerant attitude to interlocutors, observance of communication etiquette. The fourth scale - "communicative behaviour" - determined its level through the statements focused on identifying respondents' behaviour in different situations of communicative interaction [4]. The last, fifth scale "self-control of personality in communicative activity" determined the ability to manage emotions and actions in communicative contacts, restraint in speech, the ability to respond adequately to various communicative situations.

A theoretical analysis of scientific literature on the problem of communicative activity and its developed model prove interconnectedness of all its components.

As a result of statistical data processing, all items had high rates of discriminativeness and internal consistency. According to test design requirements, the developed methodology was verified for validity. It meant that scales data were correlated with indicators of corresponding scales of other methods that helped to study the indicators of subject communicative activity mentioned above.

The correlation analysis revealed statistically significant interrelations between the results of "Diagnostics of communicative activity development levels in adolescents with reduced mental development" methodology and respondents' estimations according to the corresponding scales of "Communication development" in the subscale diagnosing social competence (A. Pryhozhan); Q-sorting method on "Sociability" scale, "Technique of communication" letting you identify operational and emotionalvolitional components of communicative competence (N. Tvorogova), Communicative skills test directed to measuring the level of communicative competence and quality of communicative skills formation (L. Michelson, Yu. Hilbuch's adaption), Erickson's scale for evaluating communicative speech skills, adapted by V. Kalyagin and
L. Matsko, including speech, communication and confidence scales, "Communicative and managerial inclinations" methodology scale ("Communicative inclinations" scale), A. Zverkov and E. Eidman's test-questionnaire "Volitional self-regulation study" ("Self-control" scale) [6]. Statistically significant correlation coefficients are represented in Table 4.

At the end of methodology development averages and standard deviations were calculated for all indicators. Standardization sampling included 340 adolescents with mental retardation (12-15 years old) (see Table 5).

The data obtained within the study helped to characterize levels of communicative activity development in adolescents with mental retardation.

Adolescents with a high level of communicative activity development (more than 54 points) have the motivation to communicative interaction both of personal and social orientation, which is manifested in adequate communicative activity. These teenagers are characterized by developed communicative skills, sociability, allowing them to establish communicative relations with others, control their emotions. Consequently, they have developed communicative abilities and, therefore, build harmonious relationships with others. They are often initiators of a dialogue and can choose topics for conversation.

Adolescents with a medium level of communicative activity development (from 30 to 54 points) join communication contacts mainly after being stimulated by others, show communication activity seldom, communicative skills are not formed well enough, they contact in communication with difficulty, not always understand others, it is hard to control their emotions in communicative interaction, which negatively affects interpersonal relationships.

Teenagers with a low level of communicative activity development (less than 30 points) have a low motivation to personal and social communication, are communicatively passive, their communicative skills are almost unformed, they almost do not follow generally accepted rules of communication; their understanding of interlocutors is very poor, do not react to the comments of others, which prevents the initiation of interpersonal relations. These adolescents have problems, do not feel the emotional state of interlocutors, almost do not control their communicative behaviour, and have no tact. 
Table 4

Correlation between "Diagnostic methodology of communicative activity development levels in adolescents with mental retardation" scales and data from other methods (in conventional units)

\begin{tabular}{|c|c|c|c|c|c|c|}
\hline \multirow[b]{2}{*}{ Methods } & \multirow[b]{2}{*}{$\begin{array}{l}\text { Correlated } \\
\text { variables }\end{array}$} & \multicolumn{5}{|c|}{$\begin{array}{l}\text { Indicators of "Diagnostic methodology of communicative activity } \\
\text { development levels in adolescents with mental retardation" }\end{array}$} \\
\hline & & 恚 & 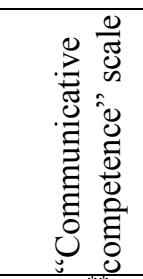 & 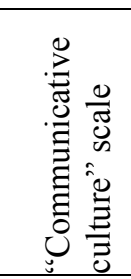 & 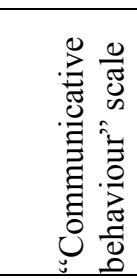 & 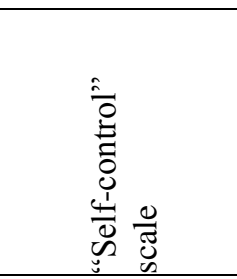 \\
\hline $\begin{array}{l}\text { A.Pryhozhan's } \\
\text { methodology }\end{array}$ & $\begin{array}{l}\text { Social com- } \\
\text { petence }\end{array}$ & $0,646^{* 3 *}$ & $0,648^{* * *}$ & $0,253^{*}$ & 0,205 & $-0,082$ \\
\hline $\begin{array}{l}\text { N.Tvorohova's } \\
\text { communication } \\
\text { technique }\end{array}$ & $\begin{array}{l}\text { Communica- } \\
\text { tive compe- } \\
\text { tence }\end{array}$ & $0,880 * *$ & $0,408 * *$ & $0,216^{*}$ & $0568 * *$ & $-0,348 *$ \\
\hline $\begin{array}{l}\text { "Communicative } \\
\text { and managerial } \\
\text { inclinations" } \\
\text { methodology }\end{array}$ & $\begin{array}{l}\text { Communica- } \\
\text { tive inclina- } \\
\text { tions }\end{array}$ & $-0,150 *$ & $0,364^{* *}$ & $0,055^{*}$ & 0,268 & 0,066 \\
\hline $\begin{array}{l}\text { Erikson's meth- } \\
\text { odology }\end{array}$ & $\begin{array}{l}\text { Communica- } \\
\text { tive and } \\
\text { speech skills }\end{array}$ & $0,866^{*}$ & $-0,308^{*}$ & $-0,241^{*}$ & $0,533^{* *}$ & $0,432^{*}$ \\
\hline $\begin{array}{l}\text { "Volitional self- } \\
\text { regulation study" } \\
\text { methodology }\end{array}$ & $\begin{array}{l}\text { Behaviour } \\
\text { self-control }\end{array}$ & $-0,080 *$ & $0,010^{*}$ & $0,226^{*}$ & $0,048^{*}$ & $0,642^{*}$ \\
\hline $\begin{array}{l}\text { L. Michelson's } \\
\text { methodology }\end{array}$ & $\begin{array}{l}\text { Communica- } \\
\text { tive skills, } \\
\text { communica- } \\
\text { tive compe- } \\
\text { tence }\end{array}$ & $0,460 *$ & $0,644 *$ & $0,520^{*}$ & $0,882 *$ & $0,428 *$ \\
\hline
\end{tabular}

** Correlation is significant at the 0,01 level (two-tailed).

* Correlation is significant at the 0,05 level (two-tailed).

Table 5.

Average values and standard deviations of "Diagnostic methodology of communicative activity development levels in adolescents with mental retardation" results

\begin{tabular}{|l|l|l|l|l|}
\hline Report & Mean & Standard deviation & Dispersion & $\begin{array}{l}\text { Standard error of } \\
\text { the mean }\end{array}$ \\
\hline 1. I like communicating with peers & 1,55 & 0,429 & 0,184 & 0,043 \\
\hline 2. I can easily get to know people & 1,24 & 0,474 & 0,225 & 0,047 \\
\hline 3. Travelling is interesting & 1,26 & 0,702 & 0,492 & 0,070 \\
\hline $\begin{array}{l}\text { 4. I don't like to talk about myself and my } \\
\text { business* }\end{array}$ & 1,28 & 0,469 & 0,220 & 0,047 \\
\hline $\begin{array}{l}\text { 5. I don't like to explain to people how to } \\
\text { get to the nearest pharmacy* }\end{array}$ & 1,32 & 0,456 & 0,208 & 0,046 \\
\hline $\begin{array}{l}\text { 6. I can always find a topic for conversa- } \\
\text { tion with people }\end{array}$ & 1,34 & 0,465 & 0,216 & 0,046 \\
\hline $\begin{array}{l}\text { 7. I will happily answer on the street how } \\
\text { to get to our school }\end{array}$ & 1,36 & 0,486 & 0,236 & 0,049 \\
\hline $\begin{array}{l}\text { 8. People around me always understand } \\
\text { what I'm speaking about }\end{array}$ & 2,54 & 0,730 & 0,533 & 0,073 \\
\hline $\begin{array}{l}\text { 9. I always tell about my school day at } \\
\text { home }\end{array}$ & 1,86 & 0,749 & 0,561 & 0,075 \\
\hline
\end{tabular}




\begin{tabular}{|c|c|c|c|c|}
\hline & & & & Table 5. \\
\hline & Mean & Standard deviation & Dispersion & $\begin{array}{l}\text { Standard error of } \\
\text { the mean }\end{array}$ \\
\hline $\begin{array}{l}\text { 10. I know how to behave in unknown } \\
\text { places }\end{array}$ & 1,82 & 0,688 & 0,473 & 0,069 \\
\hline $\begin{array}{l}\text { 11. I find it difficult to express my } \\
\text { thoughts* }\end{array}$ & 2,37 & 0,652 & 0,425 & 0,065 \\
\hline $\begin{array}{l}\text { 12. I often interrupt interlocutors to make } \\
\text { them listen to me* }\end{array}$ & 1,89 & 0,770 & 0,593 & 0,077 \\
\hline 13. I greet my acquaintances & 2,29 & 0,723 & 0,523 & 0,072 \\
\hline 14 I don't speak with nasty people at all* & 1,78 & 0,632 & 0,400 & 0,063 \\
\hline $\begin{array}{l}\text { 15. I don't communicate with some } \\
\text { classmates* }\end{array}$ & 2,05 & 0,757 & 0,573 & 0,076 \\
\hline $\begin{array}{l}\text { 16. I wish my relatives and friends happy } \\
\text { holidays }\end{array}$ & 2,46 & 0,756 & 0,572 & 0,076 \\
\hline 17. I try to be polite talking to people & 2,22 & 0,650 & 0,422 & 0,065 \\
\hline 18. If I hurt someone, I apologize & 2,46 & 0,558 & 0,312 & 0,056 \\
\hline 19. I can mock aloud at my peers* & 2,29 & 0,729 & 0,531 & 0,073 \\
\hline $\begin{array}{l}\text { 20. When I'm in a bad mood, everyone } \\
\text { knows about it* }\end{array}$ & 1,66 & 0,560 & 0,314 & 0,056 \\
\hline 21. I support conversations with pleasure & 2,34 & 0,792 & 0,627 & 0,079 \\
\hline $\begin{array}{l}\text { 22. If I've lost my friend's exercise book, } \\
\text { I will apologize then }\end{array}$ & 2,64 & 0,744 & 0,554 & 0,074 \\
\hline 23. I talk to people in a friendly way & 2,62 & 0,700 & 0,490 & 0,070 \\
\hline 24. I don't like rude people & 1,58 & 0,572 & 0,327 & 0,057 \\
\hline $\begin{array}{l}\text { 25. Sometimes I forget to comply with } \\
\text { my friends' requests }\end{array}$ & 2,34 & 0,755 & 0,570 & 0,076 \\
\hline $\begin{array}{l}\text { 26. I can hide from surrounding people } \\
\text { that there's something in them I don't like }\end{array}$ & 2,04 & 0,680 & 0,463 & 0,068 \\
\hline 27. I am often intemperate in my speech* & 1,46 & 0,626 & 0,392 & 0,063 \\
\hline 28. I overreact to insults* & 2,34 & 0,714 & 0,509 & 0,071 \\
\hline $\begin{array}{l}\text { 29. I think that those who surround me } \\
\text { can determine my mood by my facial } \\
\text { expression* }\end{array}$ & 2,15 & 0,845 & 0,715 & 0,085 \\
\hline $\begin{array}{l}\text { 30. When I am happy, I tell all my ac- } \\
\text { quaintances about it }\end{array}$ & 1,46 & 0,642 & 0,413 & 0,064 \\
\hline 31. I am reserved even in disputes & 1,66 & 0,655 & 0,429 & 0,065 \\
\hline 32. I find it difficult to control my speech & 1,78 & 0,614 & 0,377 & 0,061 \\
\hline
\end{tabular}

\section{Conclusions}

Thus, diagnostic methodology of communicative activity development levels satisfies all necessary diagnostic questionnaire design requirements and can be used when dealing with adolescents with mental retardation.

\section{REFERENCES}

1. Klein, P. (1994). Spravochnoye rukovodstvo po konstruirovaniyu testov [Reference guide to designing tests]. Kiev: Ventis [in Russian].

2. Kozyreva, V. P. (2011). Formirovaniye kommunikativnoy aktivnosti u detey d mnojestvennymi narusheniyami $\mathrm{v}$ protsesse korrektsionnoy raboty [Communicative activity formation in children with multiple disabilities in the process of correctional work]. Extended $a b$ stract of candidate's thesis. Moscow [in Russian].
The further research will be dedicated to a detailed description of diagnostic methods construct and the results of the pilot study.

3. Kolodych, O. B. (2005). Psykholohopedahohichni umovy formuvannya movlennyevoyi kompetentnosti $\mathrm{u}$ ditei iz ZPR $\mathrm{v}$ protsesi vyvchennya anhliyskoyi movy [Psycho-pedagogical conditions of speech competence formation in children with mental retardation in the process of studying English]. Extended abstract of candidate's thesis. Kyiv [in Ukrainian].

4. Korniyaka, O. M. (2006). Psykholohiya komunikatyvnoyi kultury shkolyara [Psychology of 
schoolchildren's communicative culture]. Kyiv: Milenium [in Ukrainian].

5. Nasledov, A. D. (2004). Matematicheskiye metody psikhologicheskogo issledovaniya [Mathematical methods of psychological research. Data analysis and interpretation]. Saint Petersburg: Rech [in Russian].

6. Nemov, R. S. (1995). Psikhologiya: ucheb. dlya stud. vyssh. ped. ucheb. zavedeniy: v 3 kn. Kn. 3 [Psychology: tutorial for students of higher pedagogical insti-

\section{ЛІТЕРАТУРА}

1. Клайн П. Справочное руководство по конструированию тестов / П. Клайн. - К. : Вентис, 1994. - 283 c.

2.Козырева В. П. Формирование коммуникативной активности у детей с множественными нарушениями в процессе коррекционной работы : автореф. дис. на получение науч. степени канд. пед. наук : спец. 13.00.03 / В. П. Козырева. - Москва, 2011. - 18 c.

3.Колодич О. Б. Психолого-педагогічні умови формування мовленнєвої компетентності у дітей із ЗПР в процесі вивчення англійської мови : автореф. дис. на здобуття наук. ступеня канд. психол. наук : спец. 19.00.08 / О. Б. Колодич. - К., 2005. - 18 с. tuitions: in 3 vol.]. (Vol. 3). Moscow: Prosveshcheniye [in Russian].

7. Proskurniak, O. I. (2012). Doslidzhennya komunikatyvnoyi diyalnosti osobystosti: meta, zavdannya, funktsiyi [A study of personal communicative activity: aim, tasks, functions]. Problemy suchasnoyi psykholohiyi - Issues of Modern Psychology, 18, 663-671 [in Ukrainian].

4.Корніяка О. М. Психологія комунікативної культури школяра / О. М. Корніяка. - К. : Міленіум, 2006. - 337 c.

5.Наследов А. Д. Математические методы психологического исследования. Анализ и интерпретация данных / А. Д. Наследов. - СПб. : Речь, 2004. - 338 с.

6.Немов Р. С. Психология : учеб. для студ. высш. пед. учеб. заведений : в 3 кн. Кн. 3. Экспериментальная психология и психодиагностика. - М. : Просвещение, $1995 .-512 \mathrm{c}$.

7.Проскурняк О. І. Дослідження комунікативної діяльності особистості : мета, завдання, функції / О. І. Проскурняк // Проблеми сучасної психології : зб. наук. пр. Ін-та психології імені Г. С. Костюка. - К. : Аксіома, 2012. - Вип. 18. - С. 663-671.

Олена Ігорівна Проскурняк, доктор педагогічних наук, доцент, завідувач кафедри корекційної освіти та спеціальної психології, Комунальний заклад «Харківська гуманітарно-педагогічна академія» Харківської обласної ради, провулок Руставелі, 7, м. Харків, Украӥна

\section{МЕТОДИКА ДІАГНОСТИКИ РІВНІВ СФОРМОВАНОСТІ КОМУНІКАТИВНОÏ ДІЯЛЬНОСТІ У ПІДЛІТКІВ ІЗ ЗАТРИМКОЮ ПСИХІЧНОГО РОЗВИТКУ}

Комунікативна діяльність є провідною у підлітковому віці. У підлітків із затримкою психічного розвитку у зв'язку з особливостями пізнавальної сфери вона розвивається з певними ускладненнями, що впливає на процеси їхньої соціалізації та адаптації, взаємостосунки з оточуючими. Для розробки технології розвитку та корекції комунікативної діяльності у підлітків із затримкою психічного розвитку необхідно визначити рівні сформованості комунікативної діяльності. Метою статті є висвітлення особливостей розробки психодіагностичної методики для визначення рівнів сформованості комунікативної діяльності підлітків із затримкою психічного розвитку. Для ії реалізації використовувалися методи визначення діапазону методик, які дозволяли діагностувати комунікативну діяльність підлітків із затримкою психічного розвитку, методи математичної статистики для вивірення валідності та надійності, узагальнення науково-практичних здобутків. В остаточному варіанті за розробленою методикою було обстежено 300 підлітків із затримкою психічного розвитку. Розроблена методика складається 3 п’яти шкал. Перша шкала за змістом тверджень була визначена як «комунікативна активність». Друга шкала - «комунікативні компетенції». Третя шкала - «комунікативна культура». Четверта шкала - «комунікативна поведінка». П’ята шкала - «самоконтроль особистості у комунікативній діяльності». На основі використаного діагностичного інструментарію було визначено та охарактеризовано рівні сформованості комунікативної діяльності: високий середній, низький.

Ключові слова: підлітки, затримка психічного розвитку, комунікативна діяльність, діагностика, методика, рівні, сформованість. 